\title{
Making degrowth locally meaningful: the case of the Faroese grindadráp
}

\author{
Ragnheiður Bogadóttir ${ }^{1}$ \\ Elisabeth Skarðhamar Olsen \\ University of the Faroe Islands, Faroe Islands \\ Lancaster University, UK
}

\begin{abstract}
While the doxa of growth continues to dominate mainstream understandings of what constitutes a healthy economy, the concept and agenda of degrowth beg for theorization about how culture and power render some economic strategies more viable and meaningful than others. In this article we discuss the highly contested practice of Faroese pilot whaling, grindadráp. Through autoethnographic methods we identify and analyze forces challenging this deep-rooted practice, both within and outside Faroese society. Faroese resistance to abandon the practice, expressed in local pro-whaling narratives suggest that, in the struggle to legitimize the grindadráp as a sustainable and eco-friendly practice, Faroese people are simultaneously deconstructing central tenets of the global food system, and comparing grindadráp favorably with the injustices and cruelties of industrial food procurement. In this sense, we argue that the grindadráp not only constitutes a locally meaningful alternative to growth-dominated economic practices, but may also, in this capacity, inspire Faroese people to reduce engagement with economic activities that negatively impact the environment and perpetuate social and environmental injustices in the world.
\end{abstract}

Keywords: Degrowth, whaling, Faroe Islands, relational ethic, noncapitalism.

\section{Résumé}

Alors que la doxa de la croissance continue à dominer la compréhension générale de ce qui constitue une économie saine, le concept et le programme de la décroissance implorent la théorisation savante sur la façon dont la culture et le pouvoir rendent certaines stratégies économiques plus viables et significatives que d'autres. Dans cet article, nous discutons de la pratique très contestée de la chasse à la baleine pilote féroïenne, le grindadráp. En appliqant la méthode autoethnographique, nous identifions et analysons les forces qui remettent en question cette pratique profondément enracinée, tant à l'intérieur qu'à l'extérieur de la société des îles Féroé. La résistance des Féroïens d'abandonner la pratique exprimée dans les récits locaux pro-baleiniers suggère que, dans la lutte pour légitimer le grindadráp comme une pratique écologique et durable, les Férö̈ens déconstruisent simultanément les principes fondamentaux du système alimentaire global et comparent le grindadráp favorablement avec les injustices et les cruautés de l'approvisionnement alimentaire industriel. C'est ainsi que nous soutenons que les grindadráp constituent une alternative non seulement locale aux pratiques économiques dominées par la croissance, mais peuvent aussi, à ce titre, inspirer les Féroïens à réduire leur engagement envers les activités économiques qui ont un impact négatif sur l'environnement et perpétuent les injustices sociales et environnementales dans le monde.

Mots-clés: Décroissance, chasse à la baleine, îles Féroé, éthique relationnelle, non capitalisme.

\footnotetext{
${ }^{1}$ Equal authorship. Ragnheiður Bogadóttir, PhD, Department of History and Social Sciences, University of the Faroe Islands, Faroe Islands Email: ragnheidurb "at" setur.fo. Elisabeth Skarðhamar Olsen, PhD Candidate, Lancaster Environment Centre, Lancaster University, UK. Email: e.s.olsen "at" lancaster.ac.uk. We thank Susan Paulson and Lisa Gezon for their encouragement and helpful comments and guidance. We also wish to acknowledge support and exchange of ideas with colleagues at the Department of History and Social Sciences at the University of the Faroe Islands. The content and any shortcomings in this article are the responsibility of the authors. This is the fifth article in Lisa L. Gezon and Susan Paulson (eds.) 2017. "Degrowth, culture and power", Special Section of the Journal of Political Ecology, 24: 425-xxx
} 


\section{Resumen}

Mientras que la doxa de crecimiento continúa dominando la comprensión dominante de lo que constituye una economía sana, el concepto y la agenda del decrecimiento piden la teorización sobre cómo la cultura y el poder hacen que algunas estrategias económicas sean más viables y significativas que otras. En este artículo discutimos la práctica altamente contendida de la caza de ballenas piloto de las Islas Feroe, una práctica llamada grindadráp. Mediante el método autoetnográfico identificamos y analizamos fuerzas que desafían esta práctica ancestral, tanto dentro como fuera de la sociedad de las Islas Feroe. La resistencia de los residentes a abandonar la práctica, expresada en narrativas locales pro-balleneras, sugiere que, en la lucha por legitimar la grindadráp como una práctica sostenible y respetuosa con el medio ambiente, el pueblo de Feroe está simultáneamente desconstruyendo principios centrales del sistema alimentario global y comparando favorablemente grindadráp con las injusticias y las crueldades de la adquisición industrial de alimentos. En este sentido, argumentamos que la grindadráp no sólo constituye una alternativa local a las prácticas económicas dominadas por el crecimiento, sino que también puede, en esta capacidad, inspirar a las feroeas a reducir el compromiso con las actividades económicas que perpetúan las repercusiones e injusticias sociales y ambientales en el mundo.

Palabras clave: Decrecimiento, caza de ballenas, Islas Feroe, ética relacional, no capitalismo.

\section{Introduction}

The Faroes, an archipelago of eighteen small islands in the North Atlantic Ocean with a population of less than 50,000 people, has recently become center stage of a dramatic environmental conflict. ${ }^{2}$ It revolves around the Faroese practice of pilot whaling, locally known as grindadráp. ${ }^{3}$ This deep-rooted hunting practice has been targeted by a number of environmental and conservation organizations since the mid-1980s, in later years mainly the Sea Shepherd Conservation Society (SSCS). Compelling images of grindadráp communicated via social media show whales being slaughtered on Faroese beaches by crowds of men with long knives, as the sea turns red from the bleeding animals. These anti-whaling campaigns portray the spectacle of grindadráp as an outdated tradition, barbaric, brutal, unnecessary, and sadistic. Although not yet very successful in prohibiting or preventing whale killings from taking place, the campaigns have been relatively successful in promoting a negative image of Faroese society to a global environmentally conscious audience and continue to provoke global outcry. ${ }^{4}$ The Faroese have reacted to the anti-whaling campaigns by uniting and communally engaging in a discursive struggle to defend the right to whale, portraying the grindadráp as a sustainable, environmentally friendly practice. The ongoing and often raging debates among and between Faroese, and between Faroese and protesters of pilot whaling reveal how the constant (re)negotiation of identity is intimately connected to ways in which people engage with and utilize the natural environment.

Anti-whaling narratives are typically constructed around one out of three lines of argument: First, that whaling is unnecessary since most Faroese people can afford to buy supermarket food. Second, that

\footnotetext{
${ }^{2}$ Faroes, Føroyar, or the Faroe Islands are situated roughly between Norway, Iceland and Shetland, and were settled before or around AD 600 (Church et al. 2013). Although the Faroes were incorporated into the Norwegian and later the Danish Kingdom, there has only been modest cultural assimilation, and cultural practices and traits such as the Faroese language have been retained. The Faroes gained the so-called Home Rule Act in 1948, which means in practice that most local affairs are managed and controlled by the Faroese government, while national sovereignty remains in Denmark.

${ }^{3}$ Etymologically grindadráp means pilot whale (grind) killing (dráp). The whale hunted and killed in the Faroes is the long-finned pilot whale, Globicephala melas. According to the IUCN red list website "IWC, ICES and NAMMCO have concluded, that with an estimated sub-population size of 778,000 (CV=0.295) in the eastern North Atlantic and approximately 100,000 around the Faroes (Buckland et al. 1993; NAMMCO 1997) the Faroese catch is probably sustainable" (IUCN 2015).

4 This outcry has manifested in different ways ranging from boycotts of Faroese products and tourism, to cancellations of sporting and cultural events. A large number of celebrities, ranging from Paul McCartney, to Pamela Anderson and David Attenborough have been actively involved in anti-grindadráp campaigns. Faroese official and governmental agencies receive mountains of protest mail, and Faroese people, including school children receive hate mail and death threats (Ginkel 2005, 2007).
} 
it is cruel and uncivilized to kill whales. The third argument revolves around human health, in light of the fact that pilot whales are contaminated with industrial pollutants such as mercury and PCBs.

However, the practice of grindadráp can also be conceptualized as a successful common property regime (Kerins 2010; Ostrom 1990) ingrained with values that are often associated with degrowth. In a recent article Fielding et al. (2015: 39) analyze and describe the grindadráp as "a unique and current example of Kropotkin's mutual aid" that is as an example of self-organization based on cooperation rather than competition. Moreover, no monetary transactions are involved in the social organization of labor and distribution of meat and blubber. ${ }^{5}$ In many ways then, grindadráp may be seen as a continual noncapitalist practice of production/consumption (Gibson-Graham 2006[1996]). ${ }^{6}$

Of course, grindadráp represents only one reality of contemporary Faroese society. Visitors to the Faroe Islands will quickly realize that the Faroes is a so-called welfare society, which maintains high material standards of living for most inhabitants. The Faroes have one of the highest per capita GDPs in the world ${ }^{7}$ and one of the highest per capita emissions of greenhouse gases (Lastein 2002). The national economy is dominated by industrial fisheries, proliferating aquaculture, and much effort has been put into establishing a Faroese oil industry. Economic growth and mainstream development discourse thus dominates political decision-making.

The conundrum of this hybrid geography (Fielding 2010), subsistence hunting on the one hand and industrialist on the other, is also expressed in the narrative struggle between pro- and anti-whaling positions.

Thus as a socio-ecological phenomenon, grindadráp provides a unique platform to discuss many of the issues central to what we may tentatively term the political ecology of degrowth. It highlights the discrepancies of scale that such analysis must find ways to deal with, as well as the cultural complexities in which peoples' attitudes and actions towards the environment are enmeshed. Moreover the case of the grindadráp is also an illuminating example of how relations of power influence culture-environment interactions, and of the importance of recognizing "both the biophysical basis of reality and the historical and discursive context in which knowledge of it is gathered" (Paulson and Gezon 2005: 29).

A key theoretical point of departure for this analysis is that "traditional, pre-industrial human societies have something to tell us about how to live sustainably" (Hornborg 1996: 45). This position should not be confused with essentialist idealizations of the "noble savage" and "primitive ecological wisdom" (Milton 2013 [1996]). Rather, a contextual or relational stance is one that "denies the capacity of abstract, totalizing systems such as science or the market to solve the basic problems of human survival, recognizing local and implicit meanings as the essential components of a sustainable livelihood" (Hornborg 1996: 45). The theoretical implication of such a stance is that to recognize and advance any fair, just or even plausible transition towards degrowth, locally meaningful dimensions need to be reckoned with. By advancing a non-evolutionary approach we want to make the point that contextually meaningful contemporary practices, often rooted in pre-industrial times, and not dominated by growth imperatives, continue to co-exist with modern growth dominated lifestyles. We argue that grindadráp is one example of such a practice.

Although the image of the whale, or the "superwhale" (Kalland 2009), has long been an emblem of the environmental movement, that is a metaphor in terms of which people understand the larger whole of

\footnotetext{
${ }^{5}$ Although, this is the case people are of course free to sell their share of meat and blubber, which is why it may still be bought and sold and sometimes ends up for sale in local supermarkets (for a thorough treatment of the distribution system see Joensen 2009:124-186).

${ }^{6}$ According to official statistics, the average annual catch of grind during the decade between 2005 and 2014 amounted to 4360 skinn (Hagstova Føroya 2016), or approximately 166 tons of meat (using the skinn value of $38 \mathrm{~kg}$ as proposed by Bloch and Zachariassen (1989: 45). Grindadráp thus provided on average $3.5 \mathrm{~kg}$ of whale meat, and an almost equal amount of blubber per capita a year. Skinn is an old Faroese weight and value measuring unit, originally the value of a sheepskin (Thorsteinsson 1993).

7 House of Industry [of the Faroe Islands]. 2016. Economic situation. [accessed January 162016 ]. $\underline{\text { http://industry.fo/Default.aspx?ID=3763 }}$
} 
the environmental condition (Hajer 1995: 20), to the Faroese the very practice of killing whales constitutes an alternative to growth-oriented strategies. Moreover, the analysis carried out in this article reveals that in response to the powerful global forces challenging the grindadráp, Faroese people generally defend it as an alternative to deeper integration and dependence on the global food system, an exercise which invites them to view the economy (or rather economies) as "fundamentally ethical sphere[s] of socio-ecological relations" (Burke and Shear 2014: 137), and to critically reflect upon the fetishizing tendencies of global capitalist relations of production.

\section{Contextualizing degrowth}

Degrowth signifies first and foremost a critique of the growth economy. It calls for the decolonization of public debate from the idiom of economism and for the abolishment of economic growth as a social objective. Beyond that, degrowth signifies also a desired direction, one in which societies will use fewer natural resources and will organize and live differently than today. (Kallis et al. 2014: 3 emphasis in original)

Although more than forty years have passed since the Club of Rome published Limits to growth, and in spite of abundant research documenting the incommensurability between the biophysical processes of ecosystem regeneration and a growth-oriented economy (e.g. Haberl et al. 2011; Wackernagel and Rees 1996; Rockstrom et al. 2009), the economic growth paradigm continues to thrive, albeit in greener discursive formations. Paulson (2017) points out that this paradox illustrates how systems of power and culture are embedded in socio-environmental processes, which in turn makes it crucial to emphasize relations of power and culture when theorizing change. What makes the concept of degrowth so unique and powerful is that, unlike previous concepts such as "sustainable development" and "green economy," the very semantics of the word implies less, which should make it impossible for growth-oriented discourse to co-opt it. This is also its weakness, since it expresses the antithesis of mainstream understandings of a healthy economy. "Decolonizing our imaginary" (Latouche 2014) about what constitutes a healthy economy is therefore one of the many tasks that degrowth scholars are currently engaging in.

On the basis of scholarly reviews of the degrowth literature by Demaria et al. (2013), Kallis et al. (2012) and Cattaneo et al. (2012) we find it useful to distinguish between three genres of degrowth research and theorizing, which to some degree overlap. The first concentrates on critiquing the growth paradigm and discourse of economism, and on delivering scientifically based arguments in favor of a degrowth transition or transformation. The second focuses on future scenario thinking about policies that one might implement in favor of a degrowth transition, and the third on how people and communities organize their lives according to principles associated with degrowth, such as "'sharing', 'simplicity', 'conviviality', 'care' and the 'commons'" (Kallis et al. 2014: 3). Most previous studies in this third genre have either focused on communities in the global south that organize their labor and lives in nondominant ways, or on communities in affluent societies that have consciously chosen to pursue ethical and environmentally benign lifestyles that minimize engagement in capitalist relations (see e.g. D'Alisa et al. 2014). Such studies contribute to a decolonization of the imaginary, figuring as powerful and inspiring examples of how non-dominant life practices and principles can be and are being practiced. This article contributes to this literature by exploring a non-growth oriented practice in the affluent part of the world, in which Faroe islanders engage, not because they have taken a conscious political decision to disentangle themselves from capitalism, but because it is a deep-rooted contextually meaningful practice. We thus share with Böhm et al. (2015) the view that sustainability strategies must be planned according to cultural context, and Gezon's point that "paths to sustainability may not be limited to changing social imaginaries, but may also be advanced by valorizing and leveraging cognitive orientations and practices that exist, but that may fall below the radar of traditional economic analysis." (2017:583)

The approach to degrowth advanced in this article draws significantly from the political ecology of Escobar (2008) who has made strong theoretical connection to the works of feminist economic geographers Gibson-Graham (2006 [1996]), who criticize conventional economic analyzes and 
conventional critiques of the economy for being capitalocentric, that is that they reduce the economy to a capitalist essence. Instead they argue that people everywhere engage in heterogeneous and diverse economic practices throughout their life. Gibson-Graham's studies of economic relationships are in many ways similar to studies that scholars of economic anthropology have been doing for some time (e.g. Gudeman 1986; Polanyi 1944). However, rather than understanding other economic realities (e.g. subsistence economies, gift economies) as opposite, subordinate or complimentary to capitalism, they propose a non-capitalocentric approach to economic analysis.

Gibson-Graham's non-essentialist approach to the economy makes it possible for us to stress that although the neoclassic growth-oriented market-economy currently dominates the economic landscape on the Faroe Islands, people also engage in a number of eco-cultural practices that are examples of noncapitalist economic relationships. These manifest contextually meaningful relationships between Faroese people and their environment whose significance is undermined by capitalocentric conceptions of the economy.

Another important element of our argument rests on the way that Escobar (2008) criticizes conventional theories (including critiques) of the relation between globalization, development and modernity - the eurocentric move of conceiving all forms of sociocultural organization as destined towards modernity or at best towards alternative modernities. ${ }^{8}$ Instead, Escobar emphasizes the importance of approaching development from the experience and perspectives of modernity's "Other", conceptualized as "coloniality." He suggests that from this "pluriversal" onto-epistemological position, it becomes possible to conceptualize alternatives to modernity rather than just alternative modernities.

Alternatives to modernity, then refers to that dimension of the relation between globalization, development, and modernity that imagines an explicit cultural-political project of transformation from the perspective of modernity/coloniality/decoloniality - more specifically, an alternative construction of the world from the perspective of the colonial difference (Escobar 2008: 196).

In a similar vein Burke and Shear (2014: 129) have argued that "to advance noncapitalist socioecological relations [political ecology] must... involve more than opposition and critique; it must build on already-existing noncapitalist practices in order to foment new desires and foster new political possibilities." It is this premise that informs the ambition of this article, which is to render Faroese alternatives to modernity imaginable from the perspective of a Faroese "colonial difference," namely the grindadráp.

\section{Methods}

The historical and ethnographic descriptions and analysis of grindadráp presented in this article are based on pre-existing literature and scholarly work on the issue. Much of this work is written in Faroese or other Nordic languages, and is therefore not readily accessible for a non-Nordic speaking audience. Where plausible we have tried to refer to English sources.

The analysis and classification of different narratives about Faroese pilot whaling are largely the result of autoethnographic theorizing. Although both of us have lived part of our life outside the Faroes, we were raised in the Faroes, eating whale meat and blubber as a commonsensical matter. However, neither of us has ever taken active part in the slaughter itself, one reason for this being related to the gendered dimension of the practices involved, since few women are involved in the slaughter. Throughout our lives we have also experienced the strong sentiments and aggression the issue of grindadráp can provoke among both Faroese and non-Faroese. In the late 1970s, the first reports on the high levels of pollution in pilot whales appeared and added yet another dimension to the contested meal. We have thus

\footnotetext{
${ }^{8}$ By "alternative modernities" Escobar (2008) is referring to an understanding of modernity, which leaves "open two options for development: either its universalization as a cultural and economic logic, even if without the teleology that characterized it in the past; or development as a ceaseless negotiation of modernity in terms of the counterwork that local groups necessarily effect on the elements of development and modernity and toward more self-directed forms of modernity" (Escobar 2008: 162).
} 
enthusiastically observed and followed the debates and activities of Faroese as well as non-Faroese stakeholders in the grindadráp, on social media, newspaper articles, at meetings etc., and we draw extensively on these observations in our analysis. In preparing to write this article, we have done qualitative readings of the web-page of the Sea Shepherd Conservation Society, the official web-page of the Faroese government on whaling, articles about the conflict in online newspapers, tweets with the relevant hashtags, video blogs, Facebook pages, and all the heated discussions between people in the commentary sections below these online publications/pages.

Being Faroese ourselves, we are of course engaging in the discursive struggle we have identified between Faroese people and anti-whaling protagonists. Although this is the case, we see our work as being equally a part of a process of local critical self-reflection. It has been argued that such self-criticism has always been one of several pressures for the reform of grindadráp (e.g. Sanderson 1990). Our goal here however is neither to legitimize the killing of whales nor to reform the grindadráp. By advancing an understanding of grindadráp which moves us beyond the evolutionary vocabulary of traditionalism versus modernism (or backwardness versus progress) with which both pro- and anti-whaling narratives currently seem to be fraught, we hope to convey the potential of eco-cultural practices such as the grindadráp to inspire more just and sustainable ways of being in the world.

\section{Faroese whaling}

"Grind," when used of whales, has two main meanings in modern Faroese: a school of Globiocephala melaena, and the meat from these whales, either alone or with their blubber (spik). In a sense, the whole grindadráp represents a progression from one meaning (a school of whales) to the other (meat) (Wylie 1981: 103).

The collective driving and hunting of whales has been practiced for thousands of years in many regions of the world, but the Faroes is one of the few places where such traditional whale hunting practices have continued (Kalland et al. 2005: 39). It has been argued that the practice of grindadráp predates the initial settlement of the islands, suggesting that grindadráp was a common practice in the Norse region, brought to the Faroes with Norse settlers during the $8^{\text {th }}$ and $9^{\text {th }}$ century (Thorsteinsson 1986). Archaeological excavations, and the mentioning of whale drives and distribution of whale meat and blubber in the first Faroese legal document, Seyðabrœeið from AD 1298, strongly indicates that whales were always hunted for food in the Faroes (Church et al 2005; Dahl 1970). The historical practice of grindadráp involved not only the killing of pilot whales, but a number of other procedures and institutions, such as a system of signaling to neighboring villages when a school of whales had been sighted close to shore, ${ }^{9}$ coordination of the boats participating in the whale drive (a process which could last several days, and not infrequently ended with the escape of the whales), the successful beaching of the whales, the killing itself, the butchering and dividing of the catch between participants and others entitled to shares, the celebration after a successful catch, the transportation and conservation of the meat and blubber, and finally the preparation and consumption of the grind meal. A crucial characteristic of the grindadráp is that it could not be practiced by a single family or even a single community or village; it required cooperation on a larger scale than that of the local community. ${ }^{10}$

Arguably, the practice of grindadráp and the different elements composing it have not undergone dramatic change since the $16^{\text {th }}$ century ${ }^{11}$ Still today grindadráp is an example of an important subsistence

\footnotetext{
${ }^{9}$ Pilot whales are only hunted when sighted close to shore. In other words Faroese do not go out searching for whales in the open sea. In years when no pilot whales are spotted there is no grindadráp.

${ }^{10}$ Generally speaking, traditional life in the Faroes demanded high levels of co-operation and trust, but mostly at the village level.

${ }^{11}$ However, grindadráp has of course co-evolved with Faroese society. An important change in the distribution of the meat and blubber was introduced with the whaling regulations in 1832, when it was decided that a larger proportion
} 
practice which demands cooperation between villages and, as mentioned in the introduction, it was, and continues to be, an example of "mutual aid," survival through cooperation rather than competition (Fielding et al. 2015). By stressing these characteristics of grindadráp we do not mean to argue that commercial interests were never involved. Whale products, particularly whale oil, were valued on foreign markets. Historically, export volumes have varied depending on demand and the commercial strategies of colonial authorities in the Faroes. During the 1840s for instance, whale products made out almost 20 percent of total exports (West 1972: 82). We argue however that the commercial aspect was never a single purpose or motivation for grindadráp, and that, during the twentieth century, as other spheres of life were increasingly commercialized, grindadráp came to represent an antithesis to commodification and commercialization.

Historical documentation of pilot whale catches goes back to 1584 (with an interruption in data between 1642-1708), and after 1708 statistics are reliable, making Faroese pilot whaling one of the best documented hunting practices in the world. Although there is significant variation between years and periods, the average annual catch in the Faroes today of around 800 pilot whales (Hagstova 2016), corresponds roughly to the annual average caught since 1709, of between 800-1000 whales (Bloch et al. 1990; Joensen and Zachariassen 1982). The grindadráp is therefore a concrete example of a common property regime (Kerins 2010) which has not ended in "tragedy" as human population has increased. ${ }^{12}$ While the grindadráp has changed little, Faroese society in many other respects changed dramatically. During the span of the $19^{\text {th }}$ century, the Faroes went from being a relatively self-sufficient peasant society to become a nascent fisheries nation, and during the succeeding $20^{\text {th }}$ century the Faroes became increasingly integrated into the fossil-fueled world system of global economic trade relations, thus gaining access to non-local resources upon which Faroese society depends heavily today. ${ }^{13}$ Parallel to the commercialization of the fisheries and the increasing reliance on commodities from abroad, Faroese people continued to engage in noncapitalist subsistence practices such as whaling, fowling, sheep-rearing, fishing for-use, gathering of bird eggs, cow pasturing, knitting and subsistence agriculture (Olsen 2011). This was simultaneously the period of nation-building, and together with other emblems of Faroese culture such as the Faroese language, and the traditional chain dance and ballads for instance, grindadráp came to play a crucial role in the construction of a Faroese national identity. Outside views such as travel writings and narrations of the grindadráp epitomized the bravery of Faroese men and the heroic struggle for survival which life on the islands required, portraying grindadráp for example as a "national sport." The grindadráp thus became intimately intertwined with Faroese nationhood and manhood (Nauerby 1996; Simonsen 2012; Wylie 1987), and forces challenging the grindadráp are therefore perceived and experienced by many Faroese as an attack on Faroese culture, identity and sovereignty (Joensen 2009).

With the rise of the environmental movement during the 1970s, and the important symbolism of the whale for the mobilization of popular engagement in environmental issues, outside perceptions of the grindadráp changed dramatically. This was felt in the Faroes in the 1980s when Sea Shepherd, Greenpeace and other conservation and animal-rights organizations launched campaigns against the

of the catch should be given to the participants in the whale drive rather than to land owners. Distribution of whale meat and blubber still largely follows the regulations set up in 1832, which means that the catch is distributed equally among the residents of a whaling district. In principle this means that "a new-born child receives the same amount of catch as the seasoned whaler who has been engaged in the hunt on land for several hours" (Joensen 2009: 144). In later years, regulations to reduce the stress and suffering of the whales during the drive and killing have been introduced.

${ }^{12}$ While the pilot whale catches have remained relatively stable since 1709 , the human population has grown more than 10-fold (Guttesen 1996; Mortensen 1954).

${ }^{13}$ The process started with the introduction of free trade, the abandonment of Danish trade monopolization and the repealing of the bonded production system called the Bátsbandið (boat bond) which until then had regulated fishing and catch distribution. When these changes happened in the mid- $19^{\text {th }}$ century, it became possible to sell fish to local merchants, who began accumulating capital through a truck-system, which made it possible for them to expand their business and invest in smacks and motorized boats (Olsen 2011: 23-24). 
hunting of whales, seals and other animals deemed worthy of protection. The devastating effects of these campaigns on many indigenous hunting groups and societies are well known (Kalland et al. 2005).

The anti-whaling campaigns so far have not been successful in convincing Faroese to abandon the practice of grindadráp. In a recent analysis of the Sea Shepherd campaign Grindstop 2014, Singleton argues that, on the contrary, the campaign strengthened pro-whaling sentiments (2016). Nevertheless, Faroese attitudes to whaling are changing and in 2011 a Faroese branch of the organization Earthrace Conservation was established. ${ }^{14}$ According to an opinion poll from 2014, most Faroese attitudes to end the practice of grindadráp are neither related to the animal-rights cause nor the negative health effects of consuming whale. ${ }^{15}$ The poll showed that twelve percent of the Faroese populations think the practice should be abandoned, and state their main reasons to be that it is unnecessary and that it damages the image of the Faroes in the international community. Discussions around this theme in the Faroes often reveal a utilitarian perspective, for instance pointing out that whaling has a negative impact on the tourism industry, and that the Faroes would benefit economically by abandoning the practice. The ubiquity of economism is also reflected in the tactics of anti-whaling campaigns, whether it is in instigating international economic pressure on the Faroes by portraying Faroese people as bloodthirsty savages, or less aggressive methods, such as promoting the Faroes as the next potential hot-spot for economically profitable whale-watching tourism.

We argue that the forces challenging grindadráp today are expressions of the same decontextualizing tendencies of modernity that materialize as accelerating use of resources and a loss of local meaning, and which lie at the root of the global ecological crisis (Hornborg 1996, 2001). These forces, which we have already identified in economism and capitalocentrism, are rendering grindadráp increasingly meaningless.

\section{Toxic modernity}

Another very tangible consequence of modernity is that pilot whale meat and blubber, previously an important source to nutrition and health, is now toxic. Research spurred by the increased global attention to environmental pollutants in the 1970s showed that contents of mercury and POPs ${ }^{16}$ were alarmingly high in pilot whales, and subsequent research carried out in the Faroes has shown that Faroese people have bio-accumulated high levels of these substances (Stoltenberg et al. 2003). In a birth cohort of Faroese children, for instance, mercury dose-related deficits in attention, language, and memory have been observed (Weihe et al. 2003). This research led to recommendations to limit consumption of whale meat, and in 2008 the Faroese Chief Medical Officer issued a statement announcing that pilot whale was no longer suited for human consumption (Landslæknin 2008; Weihe and Joensen 2012). In 2011, the Faroese Food and Veterinary authority issued another recommendation, which stated that adults could consume one meal of whale meat and blubber a month (about $3 \mathrm{~kg}$ annually), while girls and women should not eat blubber until after they had had children, and that they should not eat pilot whale meat before and during pregnancy (Heilsufrøðiliga 2011).

\footnotetext{
${ }^{14}$ Earthrace conservation is a non-profit organization, founded by former SSCS member Pete Bethune. According to their website (www.earthraceconservation.org) they work to end the practice of grindadráp, not as other organizations such as SSCS through conflict and confrontation, but through education and raising awareness.

${ }^{15}$ The poll was carried out by Gallup Faroe Islands for the Faroese lifestyle magazine Prei. The poll showed that the majority of Faroese are not in favor of ending the practice of grindadráp. Some 77 percent of the Faroese population above the age of 15, are of the opinion that the Faroese should continue whaling as they currently do. The same poll showed that 20 percent of the Faroese population has limited their consumption of pilot whale as a result of the health recommendations. Some 74 percent stated that they consume the same amount as before the recommendations, 1 percent stated they consumed more, 3 percent stated they had never eaten pilot whale, and 1 percent was not aware of the recommendations (Gallup Føroyar 2014). A survey on consumption habits in 1981 showed that Faroese people consumed on average $4.4 \mathrm{~kg}$ of pilot whale meat and $2.5 \mathrm{~kg}$ of pilot whale blubber annually. In comparison, a survey carried out in 2000-2001 of consumption habits of pregnant Faroese women showed that they consumed on average $1.5 \mathrm{~kg}$ of meat and $0.2 \mathrm{~kg}$ of blubber (Heilsufrøðiliga starvsstovan 2011).

${ }^{16}$ Persistent Organic Pollutants, are toxic chemical substances.
} 
The fact that pollution levels in the oceans are so high that marine mammals, which for a long time have been crucial sources of food, are now increasingly becoming unsuited for human consumption, is a situation that the Faroese share with other people in the circumpolar North. In 1998, Sheila Watt-Cloutier, then president of the Inuit Circumpolar Council of Canada expressed the emotions this stirred in Inuit communities to the Inter-Government Negotiating Committee 'Toward a Global Convention on Persistent Organic Pollutants':

So imagine for a moment if you will the emotions we now feel—shock, panic, rage, grief, despair - as we discover that the food which for generations has nourished us and keeps us whole physically and spiritually is now poisoning us. You go to the supermarket for food; we go out on the land to hunt, fish, trap and gather. The environment is our supermarket. (Watt-Cloutier 1998; quoted in Johnson 2014: 162)

In her analysis of the negotiations in 1998, Johnson (2014: 162) discusses how Watt-Cloutier "invited negotiators to think differently about the relationships between production, pollution, and human and environmental well-being by evoking emotion and the affective ties that connect Inuit to one another, to the land, and to animals." The recommendation by the Faroese Chief Medical Officer uses a similar affective language, but while Watt-Cloutier uses affect to argue for a ban on the production of polluting chemicals, the Faroese recommendation, in effect, is to end the practice of grindadráp:

It is with great sadness that this recommendation is provided. The pilot whale has served the Faroese well for many hundreds of years and has likely kept many Faroese alive through the centuries. But the times and the environment are changing, and we therefore believe that this recommendation is necessary from a human health point of view. We in the Faroe Islands are not responsible in regard to the marine pollution, which has been inflicted upon us from outside. That research in the Faroes has contributed to the current focus on this contamination is a bitter irony. These results have already led to reduced limit values on methylmercury in other countries. We must therefore also ourselves acknowledge the consequences and act according to the precautionary principle... (Weihe and Joensen 2012)

The sentiment in the Faroese statement reflects an evolutionary perception of the grindadráp that both Faroese and non-Faroese anti-whaling positions have in common, namely that grindadráp now belongs in the past, not the future.

The fact that most Faroese people continue to consume whale meat and blubber in spite of the official recommendations does not reflect ignorance of the potential health effects, nor is it simply a matter of backward "cultural stubbornness" as is frequently argued. We believe that the insistence of so many Faroese to eat pilot whale reflects a relational ethic and the significance of this contextually meaningful subsistence practice to Faroese human/cultural ecology.

\section{Narratives about grindadráp}

To understand how Faroese people render the grindadráp meaningful, it makes sense to look at Faroese responses to global anti-whaling narratives that portray grindadráp as inappropriate, unnecessary, unhealthy, uncivilized, and ultimately meaningless in a modern world.

Although both Faroese and non-Faroese pro-whaling attitudes are historically rooted in the symbolic role that grindadráp has played in the construction of Faroese national identity, contemporary Faroese pro-whaling narratives are attributing additional meanings to the practice, subscribing to global discourses of sustainability and environmental stewardship. Kalland et al. (2005) observe that this appears to be a general tendency in all Northern cultures that hunt marine mammals. The Faroese government thus describes grindadráp as a sustainable, well regulated, communal, and natural way of food 
provisioning on the Faroe Islands (Whaling.fo 2015). In an official memorandum by the Faroese Ministry of Foreign Affairs and Trade from September 2015, it is for instance pointed out that:

Catches are shared largely without the exchange of money among the participants in a whale drive and residents of the local district where they are landed.

$\cdots$

Most meat production in industrialized countries today is hidden well away from the public view. In the Faroe Islands people are familiar with the local processes by which whales, sheep and seabirds are killed for food. Faroese children grow up with an intimate knowledge and understanding of their natural environment, and it is considered natural for them to see and understand where the meat on their dinner plates comes from. (The government of the Faroe Islands 2015)

Government representatives and Faroese social media commentators defend the grindadráp for its noncapitalist characteristics: it is a non-commercial activity, it is done for food (for use, not exchange), and it is shared equally between participants and residents, and constitutes a direct relation between Faroese people and their environments.

While there is a clear tendency to criticize larger nations for polluting the natural environment and the sea, to the extent that whale meat and blubber is now unsuited for human consumption, there has been little reflection upon the fact that Faroese are actively pursuing the same economic strategy and ever more affluent lifestyles that inevitably contribute to global environmental degradation and pollution. In fact, since the first anti-whaling campaigns began to target the Faroese grindadráp, there has been a prevailing insistence from the Faroese authorities that Faroese people have the right to be both "modern" and "traditional," implying that they have the right to retain control of locally available resource and simultaneously pursue growth oriented market strategies in order to secure an ever-increasing access to global resources.

According to founder of Sea Shepherd, Captain Paul Watson ${ }^{17}$ the privileged lifestyle of most Faroese ought to render whaling unnecessary:

The Faroese enjoy one of the highest standards of living in the world with the highest income per capita in all of Europe. Their supermarkets are well stocked with anything that can be bought in Copenhagen, London or Paris. They all drive cars, own computers and enjoy the luxuries of modern industrialized society, yet many claim that they need to kill pilot whales and dolphins for meat. The truth is that some of them simply like to kill. They enjoy it. They need to see the blood spurting into the water. They need to smell and wallow in the blood and the sh*t of the dying animals. They need to hear their pitiful screams because these are the needs of sadistic psychopaths. (Watson 2015)

\footnotetext{
${ }^{17}$ Captain Paul Watson was an early member of Greenpeace in the 1970s. After his departure from Greenpeace, he founded his own group, SSCS, in 1977. Watson is a prominent marine conservationist with a number of prestigious awards on his CV. He is however also a controversial figure, who has received substantial criticism. The reason that we have chosen to quote Watson several times to illustrate anti-whaling narratives, instead of including statements by other anti-whaling protesters is because of Paul Watson's exceptional influence on contemporary animal-rights and marine conservation environmentalism, which gives reason to assume that a very large proportion of anti-whaling protestors are influenced by his views. Captain Paul Watson has 105k followers on twitter, while his organization's official twitter account, SSCS, has 232k followers. A quick search on Facebook in November 2015 gave us 87 Sea Shepherd fan pages, ten of which had more likes than there are inhabitants on the Faroe Islands (between 63,317 and 878,012 likes). One of these was specifically created for their Faroe Islands campaign and had 108,990 likes.
} 
An underlying notion of most anti-whaling rhetoric is that the killing of whales is universally wrong, a realization that should follow along with civilizing progression. Watson states that he sees this evolutionary progress happening in the Faroes:

The world is evolving and I have seen that evolution even in the Faroes from the first time I came to the Faroes in 1985, until the present. Changes have taken place and these changes have taken place because of outside pressure. No culture is an island entirely unto itself these days.

...

This atrocity will be ended, and of that I am certain because I have faith in the ability of people to evolve, and especially the young people of the Faroe Islands whose understanding of interdependence, diversity and finite resources, is on par with this same realization by young people everywhere on the planet (Watson 2014).

Although anti-whaling rhetoric varies, most anti-whaling narratives are framed according to the scheme of social and human evolution, and the phenomenon of the Faroese grindadráp - of white, modern, privileged Europeans engaging in barbaric slaughter of marine mammals - is therefore a poignant anachronism (Fielding 2010; Ginkel 2005; Nauerby 1996).

\section{The anachronism of whaling and supermarkets}

When the privileged lifestyle of the Faroese is mentioned in anti-whaling rhetoric, it is to make the point that such a lifestyle, with access to global resources, should render whaling unnecessary. In Watson's words again: "The Faeroese should be made to choose between their...supermarket-available food or their barbaric slaughter" (Watson 2012).

This argument is often received with mockery from a Faroese pro-whaling position, and antiwhaling protagonists are described as "people who do not know where the food in the supermarket comes from," as this quote below from a Facebook discussion thread in 2014 illustrates:

Come one - no matter where you are from you have to know that supermarkets do not produce food! Where do you think the food in the supermarkets comes from? How do you think they get the meat in the freezers?

In fact, both pro- and anti-whaling/hunting arguments often center on supermarkets. As we saw above Watt-Cloutier compares Inuit subsistence hunting and the supermarket as two sources of food and nourishment. As Johnson (2014: 162) notes however, Watt-Cloutier's statement "offered many more contrasts than similarities between the market-based transactions of the supermarket and the socially embedded economy of Inuit hunting," the latter being an economic practice with social and ecological ties to place. In many ways supermarkets represent the quintessential locale for the decontextualization of human metabolism from its socio-ecological source. Faroese people seem to be aware of this when they refer to the inability of anti-whaling protagonists to grasp this reality, as exemplified in the quote above. The conflict and controversy over whaling, and the reflection upon what grindadráp is, leads simultaneously to a reflection upon what a supermarket is. This can be noted in the conversations that Faroese people are having between each other, exemplified in this response to an online newspaper article in which the common anti-whaling arguments revolving around animal welfare, necessity, and health are forwarded:

Yes the meat is contaminated, but what food isn't? Almost everything we eat is contaminated one way or another... If you look at almost any meat we buy in supermarkets, then those animals lived under horrible conditions, whereas the grind lives free. So we 
should rather buy less meat from the supermarkets, than stop killing grind, and eat more grind ;-) (Authors' translation from Faroese). ${ }^{18}$

\section{Grindadráp as a force of Faroese decoloniality?}

The point that we have been trying to make this far, is that the "traditional" local subsistence economy, and the "modern" growth oriented market economy, here iconified as "grindadráp" and "the supermarket" respectively, co-exist on the Faroes and represent very different ways of engaging with the world in order to sustain human and social metabolism.

We have shown that grindadráp has characteristics that are often associated with degrowth and illustrated how the current conflict over whaling is making Faroese people reflect upon the fetishizing tendencies of the global (food) market, that is the socio-ecological exploitation and injustices embodied in supermarket commodities. Faroese are aware that one of the reasons why grindadráp attracts so much attention is exactly because there is no secrecy to the method of slaughter or distribution, as it happens out in the open, the blood not draining down the gutter of a slaughter house, but coloring the whaling bay red.

The spectacle of grindadráp has ravished foreign (and local) observers for centuries, but while outside views and perceptions during the $19^{\text {th }}$ century lead Faroese to construct grindadráp as heroic, as a national sport and so on, today, they are making Faroese people aware of other qualities of the grindadráp, qualities associated with more sustainable and eco-friendly ways of engaging with the human and non-human world. Such a view entails an understanding of the need for a "de-fetishization of commodities so that social and environmental injustices are no longer buried in the forgotten "secret life of things" but rather come to the fore and provide a referent for ethical consumption" (Burke and Shear 2014: 137). Thus the "colonial difference" of the grindadráp may potentially generate incentives for Faroese to reduce engagement with economic activities that perpetuate social and environmental injustices in the world.

\section{Conclusion}

In this article we have explored the symbolic and material dimensions of the deep-rooted nongrowth oriented practice of grindadráp. We suggest a conceptualization of the grindadráp as a "colonial difference" (Escobar 2008) that renders alternative lifeways and degrowth imaginable and contextually meaningful. The ongoing debates among and between Faroese, and between Faroese and protesters of pilot whaling have led Faroese people (including the authors of this article) to reflect upon the relevance and meaning that grindadráp has in their life. Although the growth paradigm dominates Faroese understandings of a healthy economy, the struggle to articulate the grindadráp as meaningful, in response to the forces challenging it, is inspiring Faroese people to reflect critically upon central axioms underpinning industrial capitalist processes.

\section{References}

Bloch, D and M. Zachariassen. 1989. The "skinn" values of Faroe Islands pilot whales: an evaluation and corrective proposal. North Atlantic Studies 1(1): 38-56.

Bloch, D., K. Hoydal, J.S. Joensen and P. Zachariassen. 1990. The Faroese catch of the long-finned pilot whale, bias shown of the 280 year time-series. North Atlantic Studies 2(1): 45-46.

Böhm, S, Z.P. Bharucha and J.N. Pretty. 2015. Ecocultures: towards sustainable ways of living. In S. Böhm, Z.P. Bharucha, and J.N. Pretty (eds.). Ecocultures: blueprints for sustainable communities. London: Routledge. Pp. 3-26.

\footnotetext{
18 "Ja, kjøtið er dálkað, men hvør matur er ikki tað? Næstan alt sum vit eta er dálkað á ein ella annan hátt ... Um man hyggur eftir næstan øllum kjøti, sum vit keypa í handlum, so hava tey djórini livað í ræðuligum umstøðum, har grindin livir frítt. So vit burdu heldur keypt minnið kjøt úr handlum, enn at steðga við at drepa grind, og etið meira grind ;-)"
} 
Burke, B.J. and B.W. Shear. 2014. Introduction: engaged scholarship for non-capitalist political ecologies. Journal of Political Ecology 21: 127-144.

Cattaneo, C., G. D'Alisa, G. Kallis and C. Zogrofos. 2012. Introduction: degrowth futures and democracy. Futures 44: 515-523.

Church, M.J., S.V. Arge, K.J. Edwards, P.L. Ascough, J.M. Bond, G.T. Cook, S.J. Dockrill, A.J. Dugmore, T.H. McGovern, C. Nesbitt, I.A. Simpson. 2013. The Vikings were not the first colonizers of the Faroe Islands. Quaternary Science Reviews 77: 228-232. Researchgate

Church, M.J., S.V. Arge, S. Brewington, T.H. McGovern, J.M. Woollett, Perdikaris, S, Lawson, IT, et al. 2005. Puffins, pigs, cod and barley: palaeoeconomy at Undir Junkarinsfløtti, Sandoy, Faroe Islands. Environmental Archaeology 10(2): 179-197.

Dahl, S. 1970. The Norse settlement of the Faroe Islands. Medieval Archaeology 14(1): 60-73.

D'Alisa, G., F. Demaria and G. Kallis (eds.). 2014. Degrowth: a vocabulary for a new era. New York and London: Routledge.

Demaria, F., F. Schneider, F. Sekulova. and J. Martinez-Alier. 2013. What is degrowth? From an activist slogan to a social movement. Environmental Values 22: 191-215.

Escobar, A. 2008. Territories of difference: place, movements, life, redes. Duke University Press.

Fielding, R. 2010. Artisanal whaling in the Atlantic: a comparative study of culture, conflict, and conservation in St. Vincent and the Faroe Islands. Ph.D. dissertation. Louisiana State University and Agricultural and Mechanical College.

Fielding, R., J.E. Davis Jr., and B.E. Singleton. 2015. Mutual aid, environmental policy, and the regulation of Faroese pilot whaling. Human Geography 8(3): 37-48.

Gallup Føroyar. 2014. Gallupkanning vegna Prei. April 2014. Um grind. Gallup Føroyar.

Gezon, L.L. 2017. Beyond (anti)utilitarianism: khat and alternatives to growth in Northern Madagascar. Journal of Political Ecology 24: 582-594.

Gibson-Graham, J.K. 2006 [1996]. "The" end of capitalism (as we knew it): a feminist critique of political economy; with a new introduction. Minneapolis and London: University of Minnesota Press.

Ginkel, R. Van. 2005. Killing giants of the sea: contentious heritage and the politics of culture. Journal of Mediterranean Studies 15(1): 71-98.

Ginkel, R. Van 2007. Gentle giants, barbaric beasts and whale warriors: contentious traditions, ecopolitical discourse and identity politics. MAST 6(1): 9-43.

Gudeman, S. 1986. Economics as culture: models and metaphors of livelihood. London: Routledge.

Guttesen, R. 1996. Historisk befolkningsgeografi. Topografisk Atlas Fcerøerne, Det Kgl. Danske Geografiske Selskab.

Haberl, H., M. Fischer-Kowalski, F. Krausmann, J. Martinez-Alier, and V. Winiwarter. 2011. A sociometabolic transition towards sustainability? Challenges for another great transformation. Sustainable Development 19(1): 1-14. Researchgate

Hagstova Føroya. 2016. Grind. [accessed February 4 2016]. http://www.hagstova.fo/fo/hagtalsgrunnur/vinna-og-veida/grind

Hajer, M.A. 1995. The politics of environmental discourse: ecological modernization and the policy process. Oxford: Clarendon Press.

Heilsufrøðiliga Starvstova. 2011. Kosttilmæli um at eta grind. [accessed February 6 2016]. http://www.hfs.fo/pls/portal/docs/PAGE/HFS/WWW_HFS_FO/UMSITING/KUNNANDITILFA R/KUNNANDITILFARFRABODANIR/KUNNTILFFRAMATVORUR/GRIND_0.PDF

Hornborg, A. 1996. Ecology as semiotics: outlines of a contextualist paradigm for human ecology. In P. Descola and G. Pálsson (eds.) Nature and Society. London and New York: Routledge. Pp. 45-62.

Hornborg, A. 2001. The power of the machine: global inequalities of economy, technology, and environment. Rowman Altamira. 
IUCN. 2015. Globicephala melas. The IUCN red list of threatened species. [accessed January 15 2015]. www.iucnredlist.org/details/9250/0

Joensen, J.P. 2009. Pilot whaling in the Faroe Islands. Tórshavn: Fróðskapur, Faroe University Press.

Joensen, J.S. and P. Zachariassen. 1982. Grindatøl 1584-1640 og 1709-1978. Fróðskaparrit 30: 71- 102.

Johnson, N. 2014. Thinking through affect: Inuit knowledge on the tundra and in global environmental politics. Journal of Political Ecology 21: 161-177.

Kalland, A. 2009. Unveiling the whale; discourses on whales and whaling. New York: Berghahn Books.

Kalland, A., F. Sejersen, M. Ris, and H.B. Broach. 2005. Marine mammals and northern cultures. Studies in Whaling 7, Circumpolar Research Series. Alberta: University of Alberta Press.

Kallis, G., C. Kerschner and J. Martinez-Alier. 2012. The economics of degrowth. Ecological Economics 84: $172-180$.

Kallis, G., F. Demaria, and G. D'Alisa. 2014. Introduction: degrowth. In G. D'Alisa, F. Demaria and G. Kallis (eds.) Degrowth: a vocabulary for a new era. New York and London: Routledge. Pp. 1-18.

Kerins, S. 2010. A thousand years of whaling: a Faroese common property regime. Circumpolar Research Series 12. Alberta: University of Alberta Press.

Landslæknin, 2008. Tilmæli um at gevast at eta grind. (Recommendation from the Chief Medical Officer of the Faroe Islands to the Faroese government representatives). [accessed January 15 2016]. www.landslaeknin.fo/Nyheder/Nyhed.aspx.

Lastein, L. 2002. Útleiðing av veðurlagsgassi í Føroyum 1990-2001, Heilsufrøðiliga Starvsstovan og Oljumálaráðið.

Latouche. S. 2014. Imaginary, decolonization of. In G. D'Alisa, F. Demaria and G. Kallis (eds.) Degrowth: a vocabulary for a new era. London: Routledge. Pp. 117-120.

Milton, K. 2013 [1996]. Environmentalism and cultural theory. London and New York: Routledge.

Mortensen A. 1954. Fólkatalið og ognarbýtingin um 1600. Fróðskaparrit 3: 7-59.

Nauerby, T. 1996. No nation is an island; language, culture, and national identity in the Faroe Islands. Århus: SNAI - North Atlantic Publications. Aarhus University Press.

Olsen, E.S. 2011. Meanings and practices related to fishing on the Faroes. MSc. thesis. Lund, Sweden: Lund University.

Ostrom, E. 1990. Governing the commons: the evolution of institutions for collective action. Cambridge: Cambridge University Press.

Paulson, S. 2017. Degrowth: culture, power and change. Journal of Political Ecology 24: 425-448.

Paulson, S., L. Gezon and M.J. Watts. 2005. Politics, ecologies and genealogies. In S. Paulson and L. Gezon (eds.) Political ecology across spaces, scales, and social groups. New Brunswick, New Jersey and London: Rutgers University Press. Pp. 17-40.

Polanyi, K. 1944. The great transformation: the political and economic origins of our time. New York: Farrar and Rinehart.

Rockström, J., W. Steffen, K. Noone, Å. Persson, F.S. Chapin, E.F. Lambin, T.M. Lenton, M. Scheffer, C. Folke, H.J. Schellnhuber, B. Nykvist, C.A. de Wit, T. Hughes, S. van der Leeuw, H. Rodhe, S. Sörlin, P.K. Snyder, R. Constanza, U. Svedin, M. Falkenmark, L. Karlberg, R.W. Corell, V.J. Fabry, J. Hansen, B. Walker, D. Liverman, K. Richardson, P. Crutzen and J.A. Foley. 2009. A safe operating space for humanity. Nature 461 (7263): 472-475.

Sanderson, K. 1990. Grindadráp: the discourse of drama. North Atlantic Studies 2(1): 196-204.

Singleton, B. 2016. Love-iathan, the meat-whale and hidden people: ordering Faroese pilot whaling. Journal of Political Ecology 23: 26-48.

Simonsen, K. 2012. Literature, imagining and memory in the formation of a nation. PhD dissertation. Roskilde University. 
Stoltenberg, M., A. Larsen, K. Kemp, D. Bloch and P. Weihe. 2003. Autometallographic tracing of mercury in pilot whale tissues in the Faroe Islands. International Journal of Circumpolar Health 62(2): 182-189.

The Government of the Faroe Islands. 2015. Information memorandum - community-based whaling in the Faroe Islands. Ministry of Foreign Affairs and Trade. [accessed January 16 2016]. http://cdn.lms.fo/media/6925/info-memo-grind-230915.pdf

Thorsteinsson, A. 1993. Merkur, alin og gyllin - gomul føroysk virðismeting. Frøði 1

Thorsteinsson, A. 1986. Hvussu gamalt er grindadrápið. Varðin 53: 65-66.

Wackernagel, M., and W. Rees. 1996. Our ecological footprint: reducing human impact on the earth. Gabriola Island, BC: New Society Publishers.

Whaling.fo. 2015. Whales and whaling in the Faroe Islands. [accessed January 15 2016]. www.whaling.fo.

Watson, P. 2012. Takk Heri Joensen: viking vs. viking over the grind. [accessed January 15 2016]. www.seashepherd.org/commentary-and-editorials/2012/05/08/takk-heri-joensen-viking-vs-vikingover-the-grind-534

Watson, P. 2014. Captain Paul Watson responds to a pro-whaling Faroese editorial. [accessed January 16 2016]. $\quad$ www.seashepherd.org/commentary-and-editorials/2014/08/22/captain-paul-watsonresponds-to-a-pro-whaling-faroese-editorial-664

Watson, P. 2015. Murder most foul in the Faroes. [accessed January 15 2016]. www.seashepherd.org/commentary-and-editorials/2015/06/07/murder-most-foul-in-the-faroes-714

Weihe, P. and H.D. Joensen. 2012. Dietary recommendations regarding pilot whale meat and blubber in the Faroe Islands. International Journal of Circumpolar Health 71.

Weihe, P., F. Debes, R.F. White, N. Sørensen, E. Budtz-Jørgensen, N. Keiding, P. Grandjean. 2003. Environmental epidemiology research leads to a decrease of the exposure limit for mercury. Ugeskrift for Laeger 165(2): 107-11.

West, J.F. 1972. Faroes: the emergence of a nation. London: Hurst.

Wylie, J. 1981. Grindadráp. In J. Wylie and D. Margolin (eds.) The ring of dancers: images of Faroese culture. Philadelphia: University of Pennsylvania Press.

Wylie, J. 1987. The Faroe Islands: interpretations of history. Lexington: University Press of Kentucky. 